\title{
Immunoglobulin production by coeliac biopsies in organ culture
}

\author{
G M WOOD, S SHIRES, P D HOWDLE AND M S LOSOWSKY \\ From the Department of Medicine, St. James's University Hospital, Leeds
}

SUMMARY The production of immunoglobulins by jejunal mucosa during organ culture has been studied. In 18 untreated coeliac patients the amounts of $\operatorname{IgA}$, secretory $\operatorname{IgA}$ and $\operatorname{IgM}$ in the culture medium were higher than in those from 17 normal controls. The results in 15 treated coeliac patients did not differ from the control subjects. Mucosal biopsies from patients with serum IgA deficiency produced very little IgA, but large amounts of IgG and IgM. The addition of neither Frazer's gluten fraction III, nor $\alpha$-gliadin to the culture system stimulated any additional increased secretion of immunoglobulins from the untreated coeliac patients. Production of IgA and IgM by the small bowel mucosa continues during organ culture, but that of IgG appears insignificant.

With the advent of peroral biopsy of the small bowel several studies have assessed the inflammatory infiltrate present in the jejunal mucosa of patients with untreated coeliac disease. It has become apparent that many plasma cells are present and most studies indicate that $\mathrm{IgA}$ and IgM plasma cells predominate. ${ }^{1-4}$ There is dispute, however, as to the relative and absolute increase in each immunoglobulin class in this condition. For example, IgA plasma cell density has been reported as the same as, ${ }^{12}$ higher $^{34}$ or lower ${ }^{5}$ than in controls.

Attempts to measure jejunal fluid immunoglobulins have again shown varied results, with $\operatorname{IgA}$ concentration being described as higher, ${ }^{1}$ similar to ${ }^{6}$ or lower than ${ }^{7}$ that in controls. There are problems involved in the measurement of immunoglobulins in intestinal secretions. First, it is difficult to ensure that samples are not contaminated by secretions from elsewhere in the gastrointestinal tract; bile, for example, is known to contain IgG and IgA. Secondly, the presence of proteolytic enzymes can result in the degradation of immunoglobulins, particularly $\operatorname{IgG}$ and $\operatorname{IgM}$. Thirdly, it is important to use an appropriate $11 \mathrm{~S}$ standard to measure IgA as this immunoglobulin is present in dimeric as well as monomeric form in intestinal secretions. ${ }^{9}$

A way of overcoming some of these problems is to use the technique of organ culture ${ }^{10}$ in which peroral

\footnotetext{
Address for correspondence: Dr P D Howdle, Dept. of Medicine, St. James's University Hospital. Leeds LS9 7TF.

Received for publication 27 January 1986.
}

mucosal biopsies of the small bowel are cultured in vitro for periods of up to 72 hours. Information thus far is restricted to one recent report ${ }^{11}$ in which immunoglobulin production by coeliac and noncoeliac mucosa during organ culture was assessed. Coeliac mucosa in exacerbation produced more immunoglobulin than mucosa in remission or in control mucosa. The presence of gluten in the culture medium had no consistent effect on immunoglobulin production. One of the problems with this study was that the immunoglobulins were measured by rocket immunoelectrophoresis, which was relatively insensitive for the amounts of immunoglobulin involved.

We have used the organ culture technique to assess immunoglobulin production by mucosa from treated and untreated coeliac patients, and from disease and non-disease controls. Sensitive enzymelinked immunosorbent assays (ELISA) have been used to estimate the normal immunoglobulin production of the cultured mucosal biopsies and to investigate the possible effect of gluten on such production.

\section{Methods}

CONTROL PATIENTS

Seventeen control patients were studied (mean age $37 \cdot 3$ years, range 17-75). All had small bowel biopsies of normal appearance on dissecting microscopy and histological examination. Ten were subsequently diagnosed as having the irritable bowel 
syndrome. The other seven had no evidence of gastrointestinal disease and the final diagnoses were anaemia (three), fibrosing alveolitis (two), anorexia nervosa (one) and multiple sclerosis (one). These are referred to as 'normal controls'.

BOWEL DISEASE PATIENTS

Biopsies were obtained from five patients with bowel disease. In four, the small bowel biopsy was of normal appearance on dissecting microscopy and histology. Further investigation revealed Crohn's disease affecting the lower small bowel (three patients) and colon (one patient). The fifth patient's small bowel biopsy showed partial villous atrophy; peritoneal biopsy revealed granulomas with caseation, indicating tuberculous infection.

\section{IgA DEFICIENT PATIENTS}

Four patients had selective deficiency of serum $\operatorname{IgA}$. Three of these had coeliac disease, of whom one was in remission and two were in relapse with small bowel biopsies showing subtotal villous atrophy. The fourth patient had normal small bowel histology.

UNTREATED COEIIAC PATIENTS

Eighteen patients with presumed untreated coeliac disease were studied (mean age 39.2 years, range 17-68). Small bowel biopsies in 17 had a mosaic appearance on dissecting microscopy and subtotal villous atrophy on histological examination; in one there were low complex convolutions and severe partial villous atrophy. All of the patients were taking gluten containing diets. Seventeen patients have so far shown symptomatic improvement on starting a gluten free diet and 13 have had a second biopsy which in all showed histological improvement. Four have yet to be rebiopsied and one patient, who has shown no clinical or histological improvement, is still consuming a normal diet.

TREATED COELIAC PATIENTS

Biopsies were taken from 15 coeliac patients who had been on gluten free diets for an average of 4.4 years. All had shown a good clinical response to the diet and in all of them the small bowel biopsy was either normal or showed only minor changes. The mean age of these patients was $40 \cdot 2$ years, range $17-68$.

\section{BIOPSIES}

Multiple peroral small bowel biopsies were taken, with informed consent, from the region of the duodenojejunal junction by an hydraulic multiple biopsy capsule. In all subjects this was done as part of a routine diagnostic procedure. These studies were approved by the local ethical committee.
ORGAN CULTURE TECHNIQUE

Immediately after excision, the biopsies were weighed and placed on a stainless steel mesh, positioned over the central well of an organ culture dish (Falcon Plastics Ltd, Los Angeles, California) with the villous surface of the biopsies uppermost. ${ }^{12}$ Up to three biopsies from a patient were placed on each grid. The well was then filled with culture medium at $37^{\circ} \mathrm{C}$ so as just to reach the cut surface of the biopsies. The culture medium ("control medium') consisted of Trowell's T8 medium $(6 \mathrm{ml})$, NCTC 135 medium (2 ml), L-glutamine $200 \mathrm{mM}$ $(0.2 \mathrm{ml})$ and $1 \mathrm{M}$ HEPES buffer $(0.1 \mathrm{ml})$, (all from Flow Laboratories Ltd, Ayrshire, Scotland), fetal calf serum $(1.5 \mathrm{ml})$ (Wellcome Research Laboratories, Beckenham), penicillin $1000 \mathrm{U}$ and streptomycin $1000 \mathrm{U}$. The dishes were placed in a sterile anaerobic jar which was gassed with $95 \%$ oxygen: $5 \%$ carbon dioxide for 30 minutes before being sealed and incubated at $37^{\circ} \mathrm{C}$ for $24-72$ hours. In some experiments, biopsies were incubated in culture medium containing $1 \mathrm{mg} / \mathrm{ml}$ of Frazer's gluten fraction III $^{13}$ or $100 \mu \mathrm{g} / \mathrm{ml} \alpha$-gliadin. ${ }^{14}$ After the period of culture, the medium was collected and stored at $-20{ }^{\circ} \mathrm{C}$ for up to three months. Preliminary studies showed that storage for this length of time did not significantly alter immunoglobulin concentrations.

\section{IMMUNOGLOBULIN ASSAY}

The total IgA, IgG, and IgM content of the medium after organ culture was estimated by ELISA ${ }^{15}$ using human serum as standard. Flat bottomed micro-ELISA plates (Dynatech, Billinghurst) were used as the solid phase carrier for goat polyvalent antiserum to human immunoglobulins (Sigma Chemicals, Poole) applied in $100 \mu \mathrm{l}$ aliquots diluted in coupling buffer $(0.1 \mathrm{M}$ bicarbonate, $\mathrm{pH} 9.6)$ to a final concentration of $400 \mathrm{ng} /$ well. After standing at $4^{\circ} \mathrm{C}$ overnight, the plates were washed four times in washing buffer (phosphate buffered saline, $\mathrm{pH} \mathrm{7.4}$ containing $(0.1 \%$ Tween 20 ) using a semi-automatic plate washer (Ilacon Ltd., Tonbridge). Suitable dilutions of organ culture medium and standard human serum (Seward Laboratory, Bedford) were prepared in phosphate-buffered saline containing $20 \%$ normal goat serum (PBS/NGS) and $100 \mu \mathrm{l}$ volumes were incubated in triplicate for one hour at room temperature. After washing four times as above, $100 \mu \mathrm{l}$ of goat antihuman $\operatorname{IgA}, \operatorname{IgG}$ or $\operatorname{IgM}$ alkaline phosphatase conjugate (Sigma), diluted in PBS/NGS, were added to each well and incubated for two hours at room temperature. After a final four washes, alkaline phosphatase activity was detected with p-nitrophenyl phosphate substrate (Sigma) solution, $1 \mathrm{mg} / \mathrm{ml}$ in diethanolamine- $\mathrm{MgCl}_{2}$ 
buffer (Don Whitley Scientific Ltd., Shipley) at $150 \mu \mathrm{l} /$ well. The reaction was stopped with $3 \mathrm{M}$ $\mathrm{NaOH}(50 \mu \mathrm{l} /$ well $)$ and the absorbance quantified at $405 \mathrm{~nm}$ on a 'Titertek Uniscan' plate reader (Flow Laboratories, Irvine). Blank values were obtained by adding PBS/NGS during the first step. Secretory IgA was measured by a similar method but the micro-ELISA plates were coated with sheep antihuman secretory component ( $200 \mathrm{ng} /$ well) (Seward); goat antihuman IgA alkaline phosphatase conjugate was the third layer and human colostral $\operatorname{IgA}$ was used as the standard (Sigma). The amount of $\operatorname{IgE}$ was measured by means of an Enzygnost kit (Hoechst). The immunoglobulin content of the medium was expressed in $\mu \mathrm{g}$ per $\mathrm{mg}$ of biopsy weight.
IMMUNOGLOBULIN CONTENT OF MUCOSAL BIOPSIES

In some experiments, the immunoglobulin content of the mucosa was measured. Small bowel biopsies from patients were homogenised in $50 \mathrm{mM}$ Mannitol$2 \mathrm{mM}$ Tris in a glass tube by means of a rotating Teflon pestle. The homogenate was filtered through a $60 \mu$ nylon mesh to remove debris and $10 \mathrm{mM}$ solid calcium chloride was added, with stirring. This brought about aggregation of the microsomes ${ }^{16}$ which were removed by centrifugation at $2000 \mathrm{~g}$ for 20 minutes. The resulting supernatant was spun at $35000 \mathrm{~g}$ for 30 minutes to remove brush border fragments and the immunoglobulin content of the final supernatant was measured by ELISA as above. The amount of immunoglobulin was expressed in
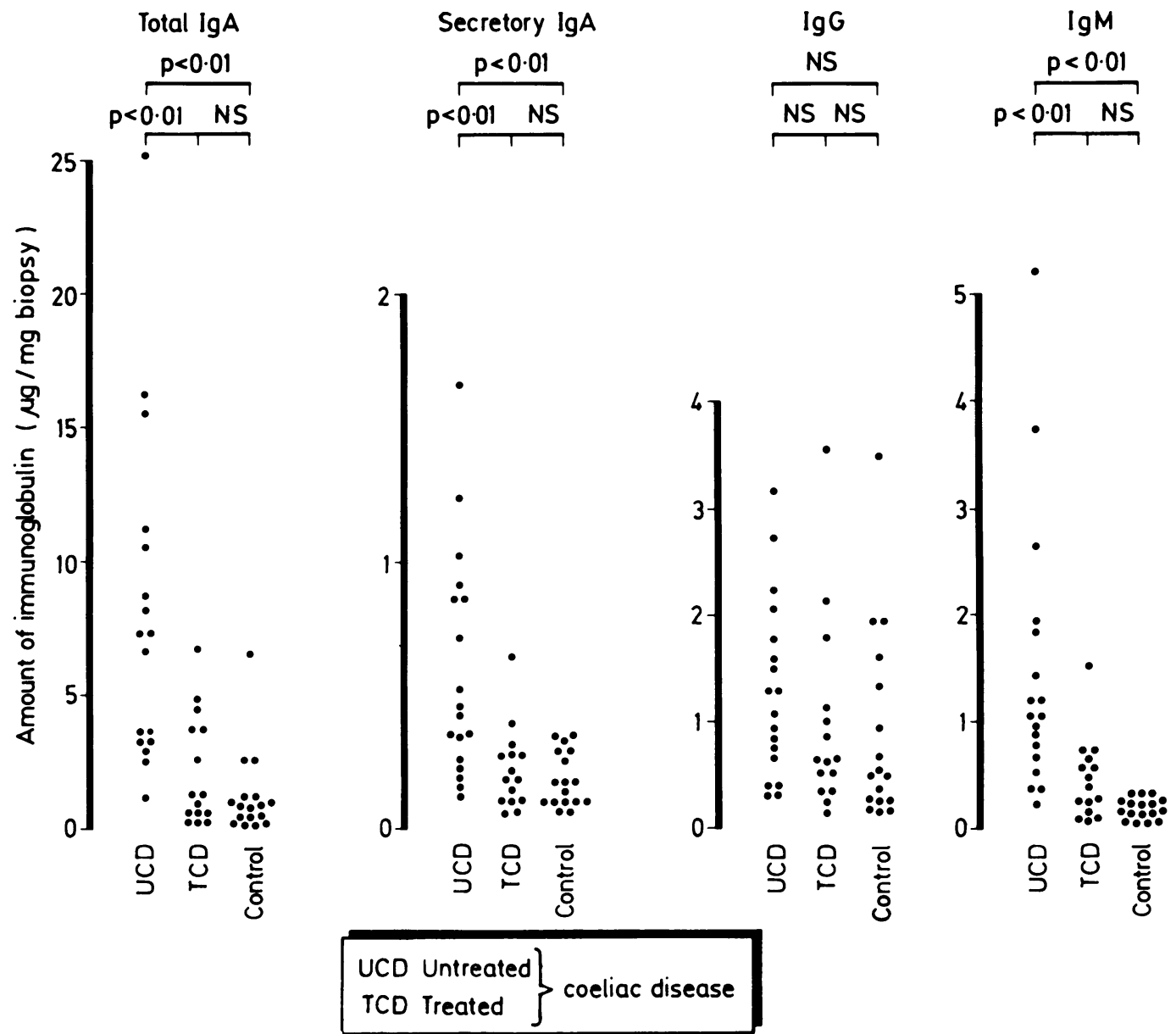

Fig. 1 Amount of immunoglobulin in culture medium after 24 hours organ culture of biopsies from coeliac and normal control patients. 
terms of the protein content of the supernatant, measured by a micromodification of the Lowry method. ${ }^{17}$ Biopsies from eight patients (one with untreated and two with treated coeliac disease, and five normal controls) were treated in this manner, the immunoglobulin content being measured in each case both in uncultured mucosa and after 24 hours culture in control medium.

\section{STATISTICAL ANALYSIS}

Statistical testing was by the paired and non-paired Wilcoxon's ranking tests as amounts of immunoglobulin produced were not normally distributed.

\section{Results}

The amounts of total $\operatorname{IgA}$, secretory $\operatorname{IgA}$, and $\operatorname{IgM}$ in the culture medium (corrected for biopsy weight) were higher in the untreated coeliac patients than in the normal control patients after 24 hours organ culture in control medium; these differences were statistically significant (Fig. 1). The median amounts of total IgA, secretory IgA and IgM in the medium from the untreated coeliac biopsies were $6 \cdot 5 \mathrm{x}, 2 \cdot 2 \mathrm{x}$, and $6 \cdot 1 \mathrm{x}$ respectively those in the culture medium from the normal control patients. The amount of IgG in the medium from the untreated coeliac group did not differ significantly from that produced by the normal controls. In the treated coeliac patients, the amounts of total $\operatorname{IgA}$, secretory $\operatorname{IgA}$ and $\operatorname{IgM}$ were significantly lower than those of the untreated patients and did not differ from the normal control patients. The amounts of IgG were similar in these groups. In four coeliac patients, the rate of immunoglobulin production fell after treatment with a gluten free diet for at least six months, apart from one patient in whom total IgA production alone was slightly increased (Fig. 2). These results show that treatment with a gluten free diet reverses the enhanced immunoglobulin production of the untreated coeliac mucosa.

The biopsies from the IgA deficient patients produced very little total $\operatorname{IgA}$ and secretory $\operatorname{IgA}$ but the amounts of IgG and IgM in the culture medium were significantly increased compared with the normal controls (Fig. 3). The amount of IgG was
Total IgA

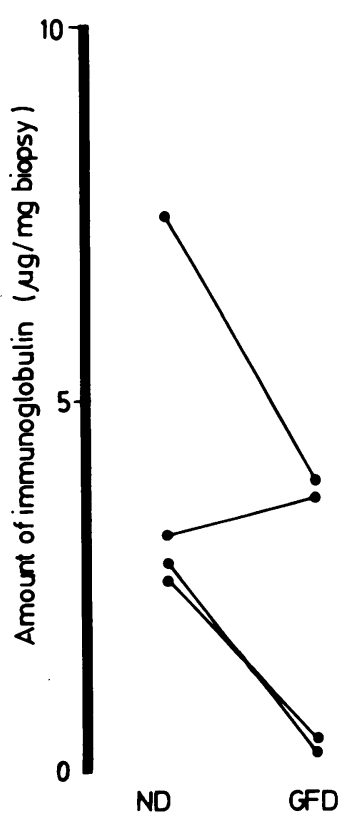

Secretory IgA

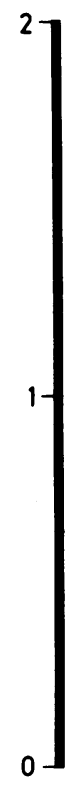

ND
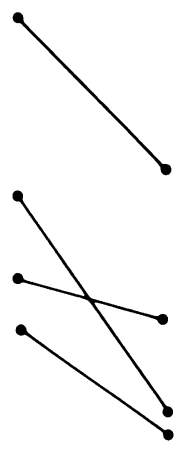

ND Normal diet GFD Gluten free diet
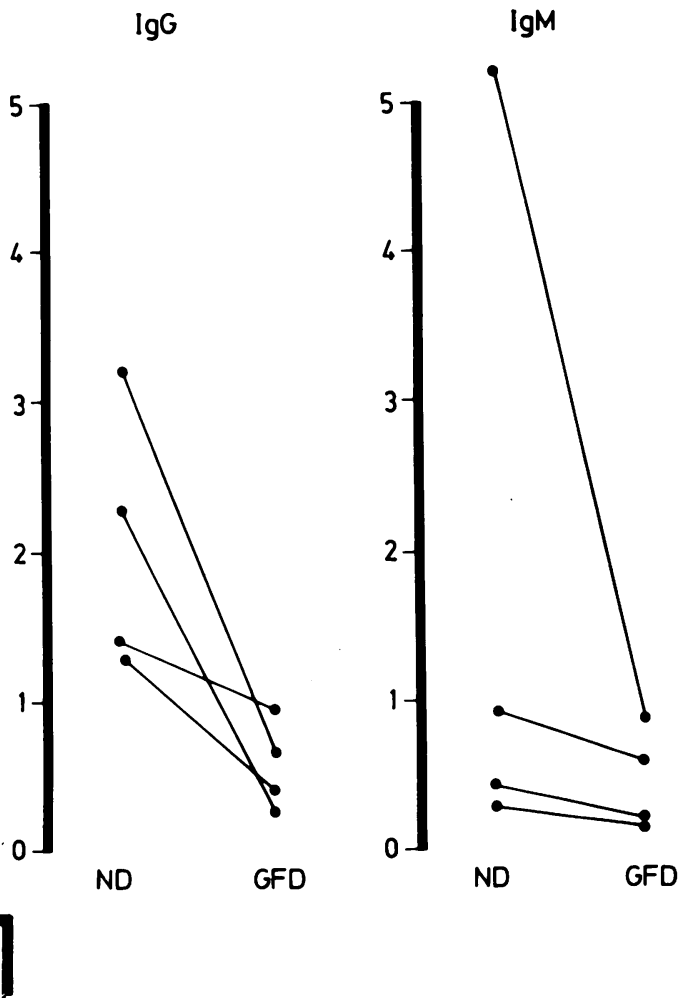

Fig. 2 Amount of immunoglobulin produced during 24 hours organ culture in coeliac patients before and after a gluten free diet. 


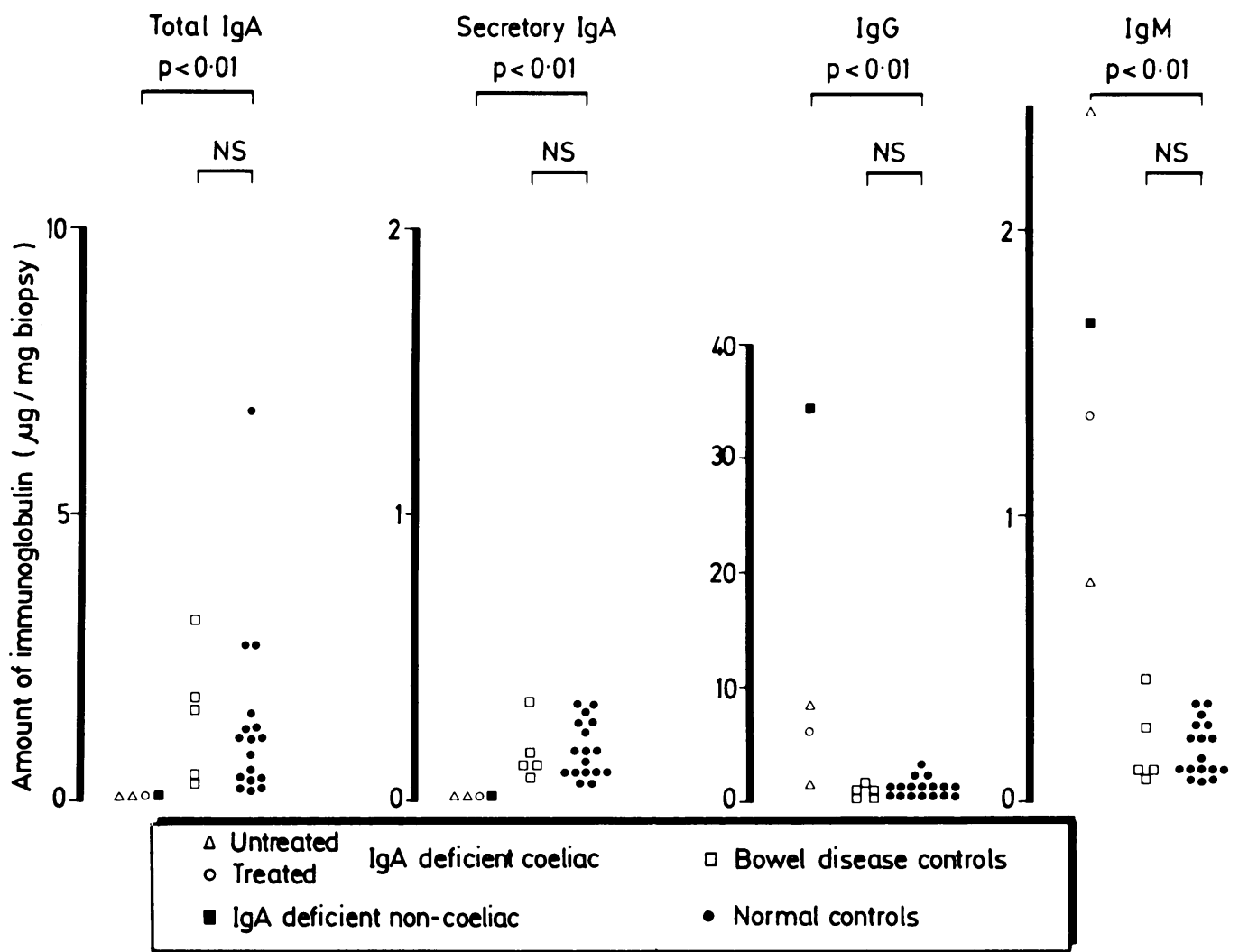

Fig. 3 Amount of immunoglobulin in culture medium following 24 hours organ culture of biopsies from IgA deficient patients, bowel disease control and normal control patients.

particularly raised. The immunoglobulin production by the biopsies from the disease controls did not differ significantly from that of the normal control patients.

When Frazer's gluten fraction III was added to the culture medium, the median amounts of total $\operatorname{Ig} \mathrm{A}$, secretory $\operatorname{IgA}, \operatorname{IgG}$ and $\operatorname{IgM}$ produced by mucosal biopsies from 16 untreated coeliac patients were similar to those produced by paired biopsies from the same patients maintained in gluten free culture medium (total IgA: 7.01 vs 7.49, secretory IgA: 0.41 vs 0.42 , IgG: 1.2 vs 1.1 and $\operatorname{IgM}: 1.0$ vs $1 \cdot 1 \mu \mathrm{g} / \mathrm{mg}$ ). These differences were not statistically significant (Fig. 4). The amounts of total $\operatorname{IgA}$, secretory $\operatorname{IgA}, \operatorname{IgG}$, and IgM produced by biopsies from the treated coeliac group in medium containing gluten fraction III were similar to those produced in control medium. The addition of $\alpha$-gliadin, as opposed to gluten fraction III, to the culture medium did not lead to any difference in the amount of immunoglobulin produced, when compared with control medium, in paired biopsies from six of the untreated coeliac patients.

Biopsies from eight subjects (two with untreated coeliac disease, two with treated coeliac disease and four control patients) were cultured for 72 hours, the culture medium being changed every 24 hours. In the case of total $\operatorname{Ig} \mathrm{A}$, secretory $\operatorname{Ig} \mathrm{A}$ and $\operatorname{IgM}$, the amount of immunoglobulin produced in each 24 hour period did not change significantly. The amount of $\mathrm{IgG}$, however, was very much lower $(\mathrm{p}<0 \cdot 01)$ in the second 24 hour period and was lower still $(\mathrm{p}<0 \cdot 01)$ in the final medium collection (Fig. 5).

In eight subjects, the amount of secretory $\operatorname{IgA}$ ( $\mu \mathrm{g} / \mathrm{mg}$ protein) in the biopsy homogenate was significantly higher $(p<0 \cdot 02)$ in the cultured than the uncultured biopsies (Fig. 6). In the case of total $\operatorname{IgA}$ and $\operatorname{IgM}$, there was no significant change in the amount of immunoglobulin in the biopsy homogenates following 24 hours organ culture. The mucosal content of IgG, however, fell significantly $(p<0 \cdot() 2)$. 

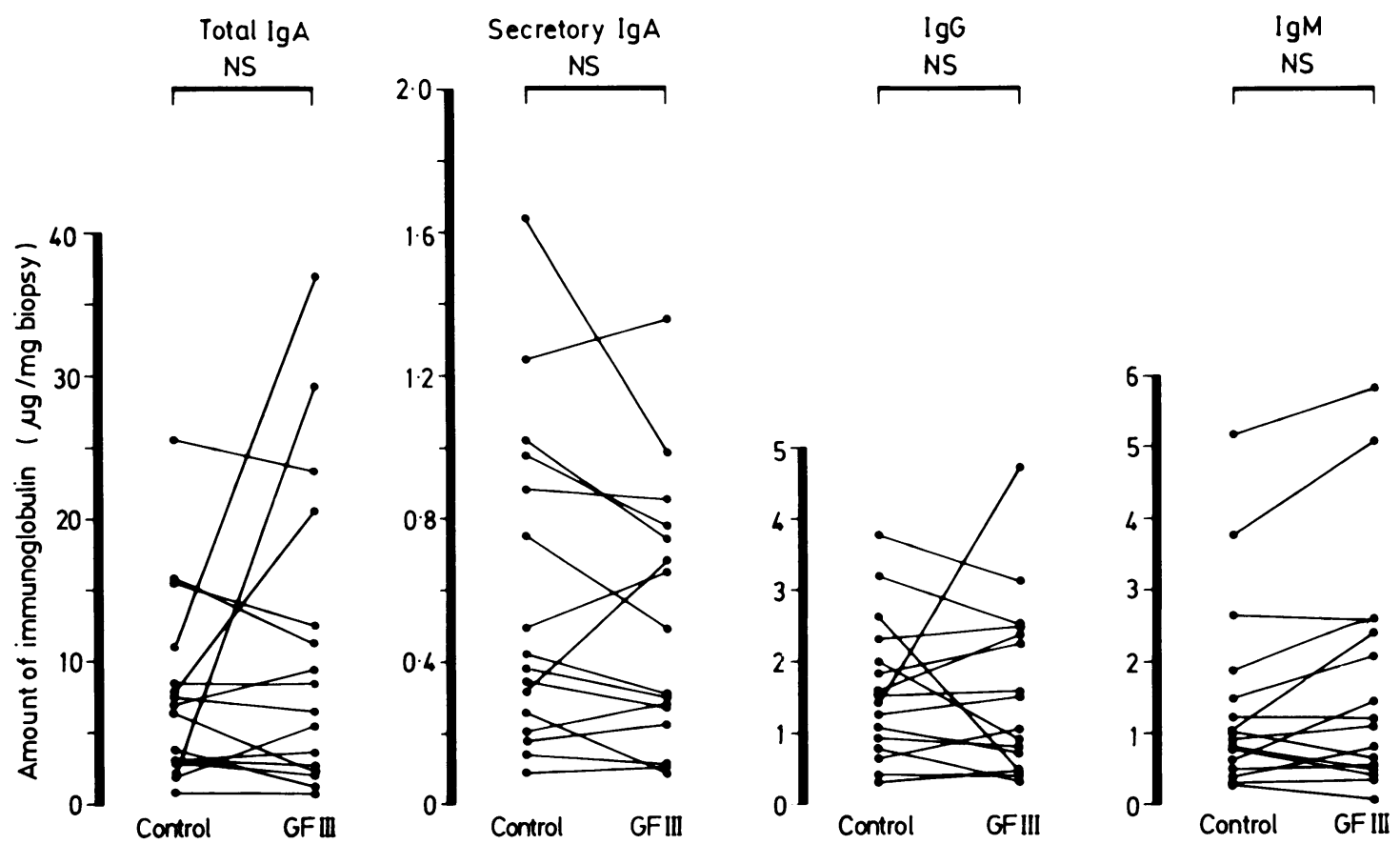

Fig. 4 Amount of immunoglobulin produced during 24 hours organ culture by untreated coeliac biopsies in control medium compared with the amount in medium containing Frazer's gluten fraction III.

IgE concentrations were measured in eight untreated coeliac patients and six control patients after 24 hours culture in control medium. In all cases the amounts were less than $5 \mathrm{iu} / \mathrm{ml}$ (the limit of sensitivity of the assay) and, therefore, insignificant.

\section{Discussion}

Previous work has indicated that functional activities, such as epithelial cell proliferation, protein synthesis, and immunoglobulin production continue during organ culture of small bowel mucosa. ${ }^{18-20}$ In 1971, Loeb et al showed that the rates of incorporation of L-leucine $-{ }^{1+} \mathrm{C}$ into $\operatorname{Ig} \mathrm{A}$ and $\operatorname{IgM}$ in treated coeliac jejunal biopsies cultured for 90 minutes were greater than in control patients, indicating that local (mucosal) production of $\operatorname{IgA}$ and IgM is increased. ${ }^{21}$ When gluten was introduced into the diet of coeliac patients, the rate of in vitro incorporation of radiolabel into IgA and IgM increased above that found on a gluten free diet. Later work showed that the rates of incorporation of ${ }^{14} \mathrm{C}$-leucine into $\mathrm{IgA}$ and $\mathrm{IgM}$ by mucosal biopsies from untreated coeliac patients were six to seven times higher than that of control biopsies. ${ }^{21}$ The rates of incorporation in patients with serum im- munoglobulin deficiencies were decreased. Falchuk and Strober then showed that about half the net increase in $\operatorname{IgM}$ and $\operatorname{IgA}$ synthesis in coeliac patients undergoing gluten challenge comprised antigliadin antibody. ${ }^{22}$

Fluge and Aksnes extended these observations by attempting to measure the immunoglobulin content of culture medium from biopsies maintained in an organ culture system for 24 hours. "It was concluded that biopsies from untreated coeliac patients released more $\operatorname{IgA}, \operatorname{IgG}$ and $\operatorname{IgM}$ into the culture medium than treated coeliac or control patients. The presence of toxic gluten fractions in the culture medium was thought to stimulate the release of increased amounts of $\operatorname{IgA}$ from untreated coeliac biopsies but such an effect was not reproducible. There are, however, some major differences between Fluge and Aksnes' study and the present one. They studied children with coeliac disease as opposed to the adult patients used here. The immunoglobulins were measured by the relatively insensitive method of rocket immunoelectrophoresis and in several experiments they were unable to detect IgM and IgG. They expressed the amount of immunoglobulin as either micrograms per biopsy ( $\operatorname{IgA}$ and $\operatorname{IgG})$ or as rocket length per biopsy (IgM) 
and, although there was a significant correlation between the amount of immunoglobulin per biopsy and the amount per biopsy wet weight, we feel the latter is a much more accurate measure and should be used routinely, as in the present results, because biopsy weights can vary considerably between biopsies when used for such methods of culture. ${ }^{23}$ Finally, the standard used for measurements of IgA was serum, which contains mostly monomeric (7S) IgA. This is known to underestimate the amount of secretory IgA present, as measured by rocket immunoelectrophoresis. ${ }^{24}$

We have measured the amount of immunoglobulin secreted into the culture medium of a large number of patients and corrected the results to take account of the biopsy weight. It is apparent that the untreated coeliac mucosa itself produces and secretes much more total $\operatorname{IgA}$, secretory $\operatorname{IgA}$ and $\operatorname{IgM}$ than either treated coeliac mucosa or mucosa from normal controls. There was no rise in production of

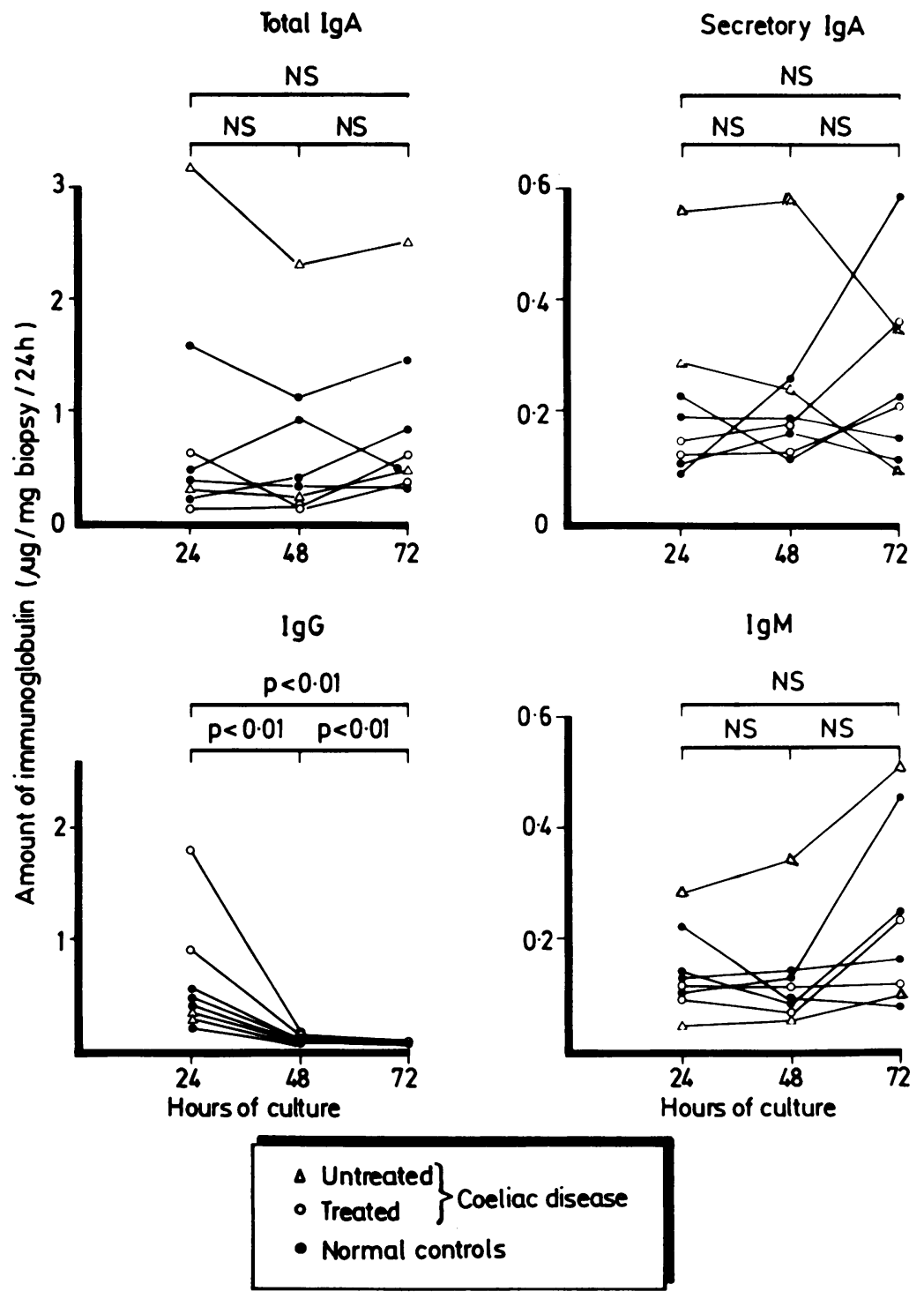

Fig. 5 Rate of immunoglobulin production during prolonged culture of mucosal biopsies. 


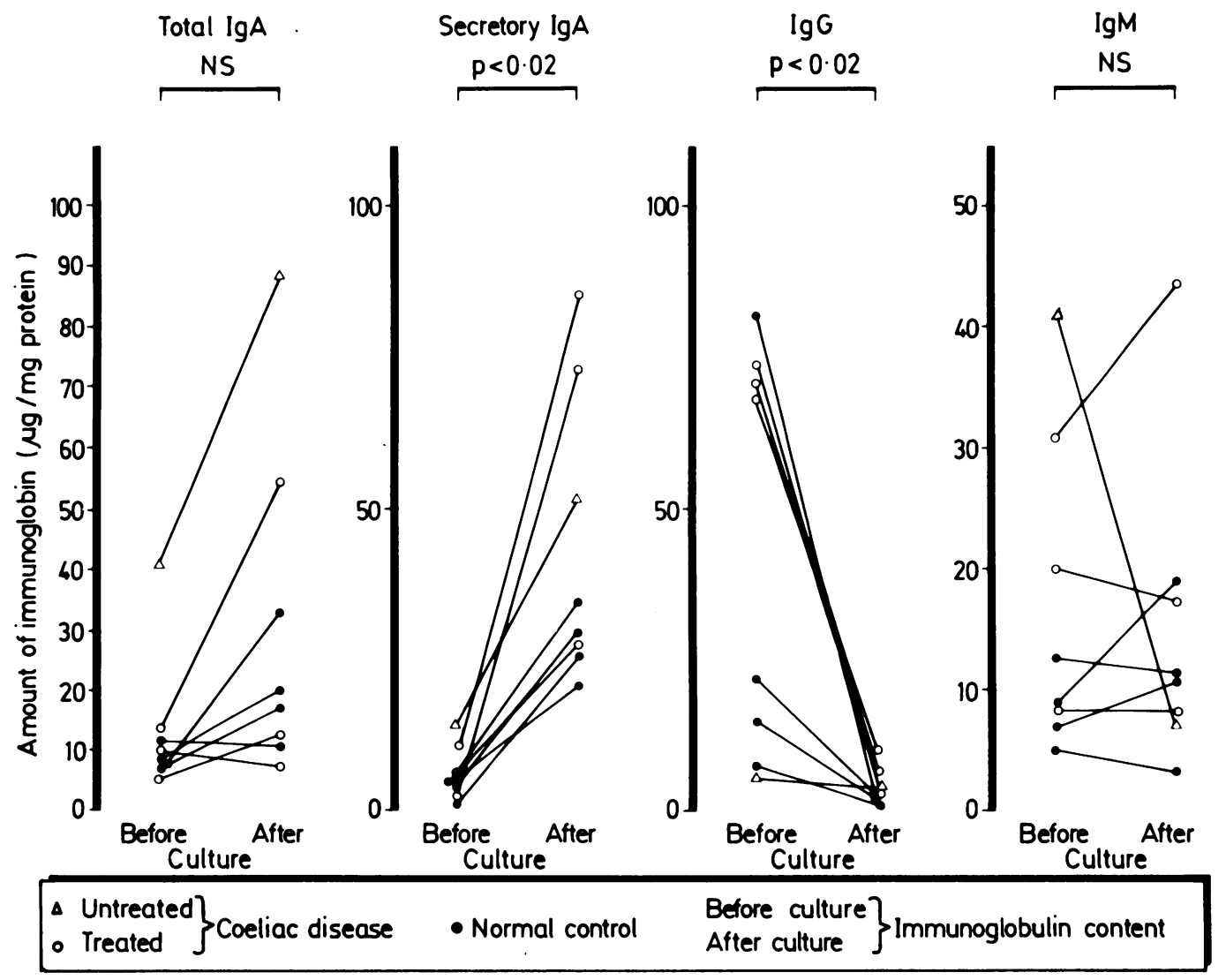

Fig. 6 Immunoglobulin content of biopsy homogenates before and after 24 hours organ culture.

IgG. These findings emphasise the importance of $\operatorname{Ig} \mathrm{A}$ and $\operatorname{IgM}$ in mucosal defence and confirm and extend the results of Loeb et $a l^{20}$ who found that the rate of $\operatorname{IgM}$ and $\operatorname{IgA}$ synthesis was increased in coeliac jejunal mucosal tissue. The absence of any difference in IgG production by untreated coeliac mucosa compared with normal mucosa in organ culture corresponds to the results of Scott et al ${ }^{4}$ who found little difference in the numbers of IgG plasma cells in the lamina propria of untreated coeliac patients compared with controls. It thus seems unlikely that IgG plays a major role in the production of the coeliac lesion. The enhanced production of total $\operatorname{IgA}$, secretory $\operatorname{IgA}$ and $\operatorname{IgM}$ may be due to the expanded population of stimulated helper $T$ cells that we have observed in untreated coeliac mucosa. ${ }^{25}$ It might be expected that the major proportion of secretory IgA produced during organ culture would collect in the mucus layer which accumulates on the villous surface of the cultured biopsy rather than entering the culture medium, as addition of secretory piece and subsequent secretion takes place from the epithelial cells lining the villi. ${ }^{26} 27$ This is supported by the large increase observed in the tissue content of secretory $\operatorname{IgA}$ following organ culture, because this included the mucus.

Production of IgE by both normal and untreated coeliac biopsies was barely detectable. This fact, coupled with the low numbers of IgE plasma cells in the coeliac mucosa, minimises the place of reaginic antibody in the pathogenesis of the coeliac lesion. ${ }^{28}$

By way of contrast, the immunoglobulin production by the biopsies from patients with other gastrointestinal diseases did not differ from that of the normal controls. This applied to the one patient in whom the small bowel mucosa was histologically abnormal. The biopsies from the IgA deficient patients produced very small amounts of total IgA and secretory $\operatorname{Ig} \mathrm{A}$ and low intestinal production of 
IgA monomer and polymers may contribute to the low level of serum IgA observed in these patients. ${ }^{29}$ The defective production of $\operatorname{IgA}$ was accompanied by hypersecretion of IgG and IgM, presumably as a form of compensation. These results mirror the changes in immunoglobulin class specific plasma cell populations seen in selective serum $\operatorname{IgA}$ deficiency. ${ }^{30} 31$

We were unable to show stimulation of immunoglobulin production in untreated coeliac biopsies when our gluten fraction III was added to the culture medium at a concentration that has been shown to be toxic to coeliac mucosa after 24 hours culture $^{12}$ and to stimulate the production of a lymphokine. ${ }^{32}$ Nor could we confirm an earlier suggestion of Fluge and Asknes ${ }^{33}$ that $\alpha$-gliadin in the culture medium may stimulate $\operatorname{IgA}$ production; the concentration of our $\alpha$-gliadin which we used in this study has been shown to produce in vitro toxicity for coeliac biopsies in organ culture. ${ }^{14}$ Study of larger numbers of patients or prolonged organ culture might clarify this situation. It is unlikely that local immune mechanisms would be maximally activated in all patients by 24 hours and longer culture periods might bring about enhanced helper $T$ lymphocyte activity in response to antigenic challenge.

The prolonged culture experiments show that the immunoglobulin content of organ culture medium is not simply caused by passive diffusion of protein from the cut surface of the biopsy without continued production of immunoglobulin by the cultured biopsies. During prolonged culture for three days, the rate of accumulation of $\operatorname{IgA}$, secretory $\operatorname{IgA}$ and IgM in the culture medium did not change. That of $\mathrm{IgG}$, in contrast, fell rapidly to very low levels, implying that local production of this immunoglobulin was insignificant. This conclusion is borne out by the fall in mucosal content of IgG after organ culture. These observations confirm studies using radiolabelled leucine which demonstrated continuing $\operatorname{IgA}$ and $\operatorname{IgM}$ synthesis in vitro. ${ }^{11} 20$

The final question raised by these experiments concerns the nature of the $\operatorname{IgA}$ and $\operatorname{IgM}$ antibodies produced by the untreated coeliac mucosa as this might have implications for the pathogenesis of the coeliac lesion. Further studies have indicated that some of the antibodies are directed against gliadin but not casein. ${ }^{34}$

These findings, therefore, show that small intestinal mucosa continues to produce IgA and IgM during organ culture, and that untreated coeliac mucosa produces these immunoglobulins in increased quantities. It remains to be shown whether the increased $\operatorname{IgA}$ and $\operatorname{IgM}$ production in untreated coeliac mucosa is purely a secondary phenomenon, perhaps representing a tissue defence mechanism, or whether it is primarily involved in the pathogenesis of the coeliac lesion by producing immunologically mediated damage.

We would like to thank The Coeliac Trust of Great Britain for financial support. We are grateful for the gift of $\alpha$-gliadin from Dr P J Ciclitira, St. Thomas' Hospital, London.

\section{References}

1 Lancaster-Smith M, Kumar P, Marks R, Clark ML, Dawson AM.. Jejunal mucosal immunoglobulincontaining cells and jejunal fluid immunoglobulins in adult coeliac disease and dermatitis herpetiformis. Gut 1974; 15: 371-6.

2 Soltoft J, Weeke B. Immunoglobulins in serum and jejunal biopsies in non-tropical sprue. Acta Med Scand 1969; 186: 459-64.

3 Scott H, Ek J, Baklien K, Brandtzaeg P. Immunoglobulin-producing cells in jejunal mucosa of children with coeliac disease on a gluten-free diet and after gluten challenge. Scand J Gastroenterol 1980; 15: 81-8.

4 Scott BB, Goodall A, Stephenson P, Jenkins D. Small intestinal plasma cells in coeliac disease. Gut 1984; 25: 41-6.

5 Pettingale KW. Immunoglobulin-containing cells in the coeliac syndrome. Gut 1971; 12: 291-6.

6 Douglas AP, Crabbe PA, Hobbs JR. Immunochemical studies of the serum, intestinal secretions and intestinal mucosa in patients with adult celiac disease and other forms of the celiac syndrome. Gastroenterology 1970; 59: 414-25.

7 Girard JP, de Kalbermatten A. Dosage et proprietes anticorps des immunoglobulines des secretions duodenales de la maladie coeliaque. Ann Immunol (Inst Pasteur) 1973; 124: C:555-65.

8 Tomasi TB. Structure and function of mucosal antibodies. Ann Rev Med 1970; 21: 281-98.

9 Samson RR, McClelland DBL, Shearman DJC. Studies on the quantitation of immunoglobulin in human intestinal secretions. Gut 1973; 14: 616-26.

10 Browning TH, Trier JS. Organ culture of mucosal biopsies of human small intestine. J Clin Invest 1969; 48: 1423-32.

11 Fluge G, Aksnes L. Quantification of immunoglobulins after organ culture of human duodenal mucosa. $J$ Pediatr Gastroenterol Nutr 1983; 2: 62-70.

12 Howdle PD, Corazza GR, Bullen AW, Losowsky MS. Gluten sensitivity of small intestinal mucosa in vitro: quantitative assessment of histologic change. Gastroenterology 1981; 80: 442-50.

13 Frazer AC, Fletcher RF, Ross CAC, Shaw B, Sammons HG, Schneider R. Gluten-induced enteropathy. The effect of partially digested gluten. Lancet 1959; ii: $252-5$.

14 Howdle PD, Ciclitira PJ, Simpson FG, Losowsky MS. Are all gliadins toxic in coeliac disease? An in vitro study of $\alpha, \beta, \gamma$ and $\omega$ gliadins. Scand $J$ Gastroenterol 1984; 19: 41-7. 
15 Voller A, de Savigny D. Enzyme linked immunosorbent assay (ELISA). In: Thompson RA, ed. Techniques in clinical immunology. Oxford: Blackwell Scientific, 1981.

16 Schenkman JB, Cinti DL. Hepatic mixed function oxidase activity in rapidly prepared microsomes. Life Sci 1972; 11: 247-57.

17 Peterson GL. A simplification of the protein assay method of Lowry et al. which is more generally applicable. Anal Biochem 1977; 83: 346-56.

18 Trier JS, Browning TH. Epithelial-cell renewal in cultured duodenal biopsies in celiac sprue. $N$ Engl J Med 1970; 283: 1245-50.

19 Kagnoff MF, Serfilippi D, Donaldson RM. In vitro kinetics of intestinal secretory $\operatorname{IgA}$ secretion. $J \mathrm{Im}$ munol 1973; 110: 297-300.

20 Loeb PM, Strober W, Falchuk ZM, Laster L. Incorporation of L-leucine- ${ }^{14} \mathrm{C}$ into immunoglobulins by jejunal biopsies of patients with celiac sprue and other gastrointestinal diseases. J Clin Invest 1971; 50: 559-69.

21 Falchuk ZM, Strober W. Increased jejunal immunoglobulin synthesis in patients with non-tropical sprue as measured by a solid phase immuno-adsorption technique. J Lab Clin Med 1972; 79: 1004-13.

22 Falchuk ZM, Strober W. Gluten-sensitive enteropathy: synthesis of antigliadin antibody in vitro. Gut 1974; 15: 947-52.

23 Howdle PD. Organ culture of human small intestinal mucosa, with particular reference to coeliac disease. University of Leeds: MD Thesis, 1985.

24 Peppard JV. Quantitative estimation of IgA in rats: a comparison of two methods. J Immunol Methods 1979; 31: 129-39.

25 Malizia G, Trejdosiewicz LK, Wood GM, Howdle PD, Janossy G, Losowsky MS. The microenvironment of coeliac disease: T-cell phenotypes and expression of the T2 "T-blast" antigen by small bowel lymphocytes. Clin Exp Immunol 1985; 60: 437-46.

26 Brandtzaeg P. Transport models for secretory $\operatorname{IgA}$ and secretory IgM. Clin Exp Immunol 1981; 44: 221-32.

27 Jonard PP, Rambaud JC, Dive C, Vaerman JP, Galian A, Delacroix DL. Secretion of immunoglobulins and plasma proteins from the jejunal mucosa. Transport rate and origin of polymeric immunoglobulin A. J Clin Invest 1984; 74: 525-35.

28 Hobbs JR, Hepner GW, Douglas AP, Crabbe PA, Johansson SGO. Immunological mystery of coeliac disease. Lancet 1969; ii: 649-50.

29 Kutteh WH, Prince SJ, Mestecky J. Tissue origins of human polymeric and monomeric IgA.J Immunol 1982; 128: 990-5.

30 Brandtzaeg P, Fjellanger I, Gjeruldsen ST. Immunoglobulin $\mathrm{M}$ : local synthesis and selective secretion in patients with immunoglobulin A deficiency. Science 1968; 160: 789-91.

31 Brandtzaeg P. Human secretory immunoglobulins. II. Salivary secretions from individuals with selectively excessive or defective synthesis of serum immunoglobulins. Clin Exp Immunol 1971; 8: 69-85.

32 Howdle PD, Bullen AW, Losowsky MS. Cell mediated immunity to gluten within the small intestinal mucosa in coeliac disease. Gut 1982; 23: 115-22.

33 Fluge G, Aksnes L. In vitro assessment of gluten toxicity by organ culture of human duodenal mucosa. In: McNicholl B, McCarthy CF, Fottrell PF, eds. Perspectives in coeliac disease. Lancaster: MTP Press, 1978.

34 Ciclitira PJ, Ellis HJ, Wood GM, Howdle PD, Losowsky MS. Gliadin antibody secretion by coeliac jejunal mucosa. [Abstract]. Gut 1984; 25: Al190. 